\title{
KONSEP PENDIDIKAN KARAKTER DALAM PERSPEKTIF HADITS
}

\author{
Abdul Fattah ${ }^{1}$ \\ Pendidikan Agama Islam Fakultas Agama Islam| Unismuh Makassar
}

\begin{abstract}
ABSTRAK
Pendidikan karakter adalah menanamkan karakter tertrtu sekaligus ,memberikan benih agar peserta didik mampu menumbuhkan karakter khasnya pada saat menjalani kehidupan di masyarakat. Dengan menjalani sejumlah gagasan atau model karakter tidak akan membuat peserta menjadi kratif, namun membutuhkan sebuah konsep yang matang mampu menumbuhkan karekter siswa. Salah satu konsep pendidikan karakter yang telah lama dibuat oleh Rasulullah lewat Hadits-haditsnya. Konsep pendidikan karakter yang digambarkan dalam hadist Rasulullah sangat penting untuk di kembangkan dan dipelajari. Adapun kualitas hadis tentang konsep pendidikan karakter adalah dari sanad maka hadis bersatus sahih li zatihi, demikian juga dari sahih segi matan. Sementara konsep pendidikan karakter dalam hadits ada dua. Pertama, pembentukan karakter yang didasari keteladanan akan menuai kebaikan bagi dirinya sendiri dan orang lain. Oleh karenanya pengaruh keluarga sebagai tempat pendidikan pertama bagi sang anak harus berupa orang-orang yang baik pula. Kedua,dalam pandangan Islam, manusia lahir di dunia ini membawa fitrah,potensi, kemampuan dasar, atau pembawaan (hereditas).
\end{abstract}

Kata Kunci: Pendidikan Karakter, Perspektif Hadits

\begin{abstract}
Character education is to instill certain character at once, giving the seeds so that learners are able to cultivate its distinctive character at the time into the life of the community. By taking some ideas or models will not make the character become creative participants, but requires a mature concept was able to grow the character of students. One concept of character education that have long been made by the Prophet through the Hadith-hadith. The concept of character education that is described in the hadith the Prophet is very important to be developed and studied. As for the quality of the hadith about the concept of character education is of sanad become Shahih li zatihi, as well as valid in terms of honor. While the concept of character education in the hadith there are two. First, the establishment of which is based on the exemplary character will reap goodness for himself and others. Therefore, the influence of family as the first school for the children should be good ones anyway. Secondly, in the view of Islam, man is born in this world bring the nature, potential, basic abilities, or nature (heredity).
\end{abstract}

\section{Keyword: Character Education, Hadith Perspektif}




\section{PENDAHULUAN}

Berbicara mengenai pendidikan, tema diskusi dan seminar yang marak akhir-akhir ini adalah tentang pendidikan karakter, bukan hanya karena terpengaruh oleh isu yang dilontarkan oleh Menteri Pendidikan Nasional tentang tema

dalam Peringatan Hari Pendidikan Nasio nal tahun 2010 ini, "Pendidikan Karakter untuk Membangun Peradaban Bangsa", tetapi juga karena keprihatinan yang sama di berbagai kalangan masyarakat.

Berbagai diskusi itu diselenggarakan untuk mencari akar penyebabnya, dan selanjutnya jika mungkin berusaha menemukan jalan keluarnya, untuk mengurangi rasa prihatin itu. Sudah barang tentu persoalan itu bukan hal ringan, bisa dijawab dengan cepat dan mudah. Persoalannya sudah sedemikian berat dan rumit. Ada berbagai variabel penyebab yang terlanjur terjadi, dan tidak bisa dihapus. Kemerosotan akhlak tersebut adalah merupakan akibat, sedangkan sebabsebab yang mendahului sudah terjadi, karena itu tidak akan mungkin dihilangkan atau ditarik kembali (Suprayogo, 2015: 1).

Jika ingin mengurai, mengapa keadaan tersebut terjadi, kiranya perlu merenungkan peristiwa-peristiwa beberapa tahun terakhir di negeri ini. Sejak tahun 1998 yang lalu, ketika terjadi reformasi, sehari-hari di kampuskampus, hingga di kota-kota kecil, dan bahkan di tingkat desa terjadi demonstrasi yang seolaholah tidak ada henti-hentinya. Dalam setiap demo itu selain mereka membawa poster-poster bernada protes, juga melontarkan teriakan-teriakan yang bernada mengolok-olok, dan bahkan juga menghujat terhadap mereka yang dianggap keliru atau salah dalam mengambil kebijakan (Suprayogo, 2015: 1).

Maka dalam waktu yang cukup lama, muncul generasi yang pekerjaannya sehari-hari menyalahkan terhadap generasi sebelumnya. Siapapun dianggap salah, apalagi pejabat pemerintah. Dengan begitu sopan santun terhadap generasi tua, termasuk terhadap orang tua, guru, pemimpin menjadi hilang.

Wacana tentang pendidikan karakter yang dikenal oleh dunia telah digagas oleh Dr. Thomas Lickona, seorang profesor pendidikan dari Cortland University pada tahun 1991, namun menurut penulis, penggagas pembangunan karakter pertama kali adalah Rasulullah SAW. Pembentukan watak yang secara langsung dicontohkan Nabi Muhammad SAW merupakan wujud esensial dari aplikasi karakter yang diinginkan oleh setiap generasi. Secara asumtif bahwa keteladanan yang ada pada diri Nabi menjadi acuan perilaku bagi para sahabat, tabi'in dan umatnya. Namun, sampai abad 15 sejak Islam menjadi agama yang diakui universal ajarannya, penerapan pendidikan karakter justru dipelopori oleh negara-negara yang penduduknya minoritas muslim.

Namun, untuk mewujudkan generasi Qur'ani sebagaimana yang dicontohkan oleh Rasulullah bukan pekerjaan yang mudah. Ia harus diusahakan secara teratur dan 
berkelanjutan baik melalui pendidikan informal seperti dalam keluarga, pendidikan formal atau melalui pendidikan non formal (masyarakat).

Generasi Qur'ani tidak lahir dengan sendirinya, tetapi ia dimulai dari pembiasaan dan pendidikan dalam keluarga, misalnya menanamkan pendidikan agama yang sesuai dengan tingkat perkembangan-nya, sebagaimana hadits Nabi: "Perintahlah anak-anakmu mengerjakan shalat, lantaran ia sudah berumur 7 tahun, pukullah mereka setelah mereka berumur 10 tahun dan pisahkan tempat tidurmu dan tempat tidur mereka" (HR. Abu Daud) (alMunawwar, 2002:353).

Dari pemaparan latar belakang di atas maka, ada dua yang menjadi poin penting dalam pembahasan ini. Pertama, bagaimana kualitas hadis tentang konsep pendidikan karakter. Kedua, Bagaimana Hadits mengkaji tentang konsep pendidikan karakter.

\section{METODE PENELITIAN}

Penelitian ini bersifat kajian kepustakaan (library research) yang bersifat kualitatif, dengan pendekatan Pendekatan secara Klasik (Naqliyyah, Aqliyyah, Sufistik) dan Pendekatan secara Kontemporer.

Metode yang digunakan dalam penelitian ini adalah maudu'i. Adapun langkah-lanngkah penelitian metode hadis maudu' $i$ adalah:

a. Menentukan tema atau topik pembahasan.

b. Melakukan takhrij al-hadits untuk mengetahui ada atau tidaknya mendukung, baik berupa syahid atau tabi' dan periwayatan secara makna serta tanawwu' dilengkapi dengan i'tibar;

c. Melakukan klasifikasi hadis, baik dari segi kandungan maupun dan segi tertib wurud nya.

d. Jika hadis bersangkutan berkualitas sahih atau hasan

\section{HASIL DAN PEMBAHASAN}

\section{A. Pengertian Pendidikan Karakter}

Istilah karakter digunakan secara khusus dalam konteks pendidikan baru muncul pada akhir abad ke 18, terminologi karakter mengacu pada pendekatan (approach) idealis spiritualis dalam pendidikan yang juga dikenal dengan teori pendidikan normatif, dimana yang menjadi priorit as adalah nilai-nilai transenden yang dipercaya sebagai motivator dan dinamisator sejarah, baik bagi individu maupun bagi perubahan sosial (Ni'matulloh, 2016: 1).

Doni A. Koesoema menengarai pendidikan karakter sudah dimulai dari Yunani. Dari zaman inilah dikenal konsep arête (kepahlawanan) dari bangsa Yunani, kemudian konsepsi Socrates yang mengajak manusia untuk memulai tindakan dengan "mengenali diri sendiri" dan "ilusi pemikiran akan kebenaran”. Doni A. Koesoema juga menjelaskan keseluruhan historis pendidikan karakter dengan urutan: homeros, hoseiodos, Athena, Socrates, Plato, Hellenis, Romawi, Kristiani, Modern, Foerster, dan seterusnya ( QAnees dan Hambali, 2008: 100).

Dalam kacamata Islam, secara historis pendidikan karakter merupakan misi utama para nabi. Muhammad 
Rasulullah sejak dari awal tugasnya memiliki suatu pernyataan yang unik, bahwa dirinya diutus untuk menyempurnakan karakter (akhlak). Manifesto Muhammad Rasulullah ini mengindikasikan bahwa pembentukan karakter merupakan kebutuhan utama bagi tumbuhnya cara beragama yang dapat men-ciptakan peradaban. Pada sisi lain, juga menunjukkan bahwa masingmasing manusia telah memiliki karakter tertentu, namun belum disempurnakan ( Q-Anees dan Hambali, 2008: 100).

\section{Menurut} Bambang Q-

Anees dan Adang Hambali, ada dua paradigma dasar pendidikan karakter:

a. Paradigma yang memandang pend idikan karakter dalam cakupan pemahaman moral yang sifatnya lebih sempit. Pada paradigma ini disepakati telah adanya karakter tertentu yang tinggal diberikan kepada peserta didik.

b. Kedua, melihat pendidikan dari sudut pandang pemahaman isu-isu moral yang lebih luas. Paradigma ini memandang pendidikan karakter sebagai sebuah pedagogi, menempatkan individu yang terlibat dalam dunia pendidikan sebagai pelaku utama dalam pengembangan karakter. Paradigma memandang peserta didik sebagai agen tafsir, penghayat, sekaligus pelaksana nilai melalui kebebasan yang dimilikinya.

Pendidikan karakter yang berbasis Al-Qur'an dan Assunnah, gabungan antara keduanya yaitu menanamkan karakter tertentu sekaligus memberi benih agar peserta didik mampu menumbuhkan karakter khasnya pada saat menjalani kehidupannya.
Hanya menjalani sejumlah gagasan atau model karakter saja tidak akan membuat peserta kreatif yang tahu bagaimana menghadapi perubahan zaman, sebaliknya membiarkan sedari awal agar peserta didik mengembangkan nilai pada dirinya tidak akan berhasil mengingat peserta didik tidak sedari awal menyadari kebaikan dirinya. (Ni'matulloh, (http://nimatulloh. blogspot.com 2016).

\section{B. Landasan Normatif}

1. Al-Qur'an

a. Q.S. al-Ra'd (13): 11.

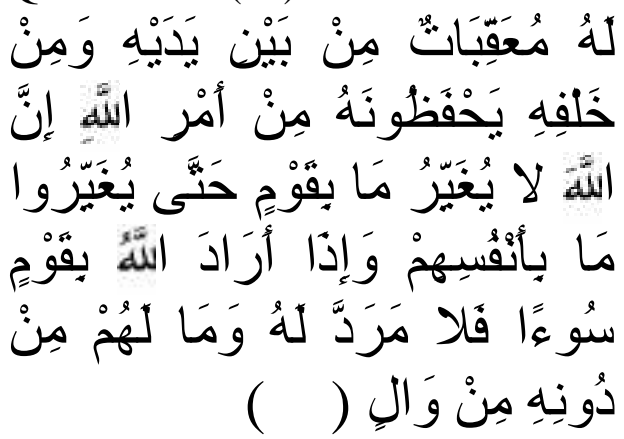

Terjemahannya:

"Bagi manusia ada malaikatmalaikat yang selalu mengikutinya bergiliran, di muka dan di belakangnya, mereka menjaganya atas perintah Allah. Sesungguhnya Allah tidak merobah Keadaan sesuatu kaum sehingga mereka merobah keadaan yang ada pada diri mereka sendiri. dan apabila Allah menghendaki keburukan terhadap sesuatu kaum, Maka tak ada yang dapat menolaknya; dan sekali-kali tak ada pelindung bagi mereka selain Dia”. (Departemen Agama) 
b. Q.S. al-Ah\}zab (33): 21

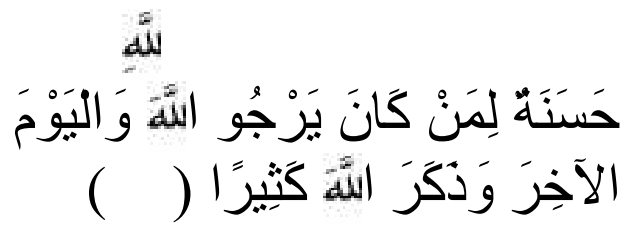

Terjemahannya:

Sesungguhnya telah ada pada (diri) Rasulullah itu suri teladan yang baik bagimu (yaitu) bagi orang yang mengharap (rahmat) Allah dan (kedatangan) hari kiamat dan Dia banyak menyebut Allah.

c. Q.S. al-Mumtahanah (60): 6

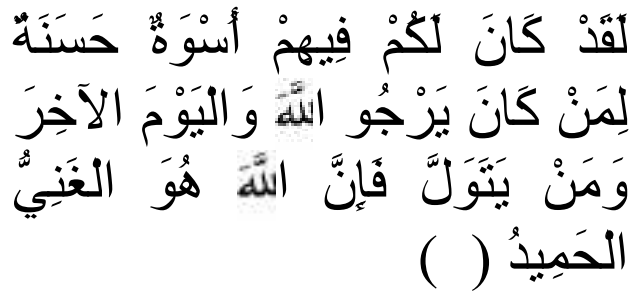

Terjemahannya:

Sesungguhnya pada mereka itu (Ibrahim dan umatnya) ada teladan yang baik bagimu; (yaitu) bagi orang-orang yang mengharap (pahala) Allah dan (keselamatan pada) hari kemudian. dan Barangsiapa yang berpaling, Maka Sesungguhnya Allah Dia-lah yang Maha Kaya lagi Maha Terpuji.

2. Hadis

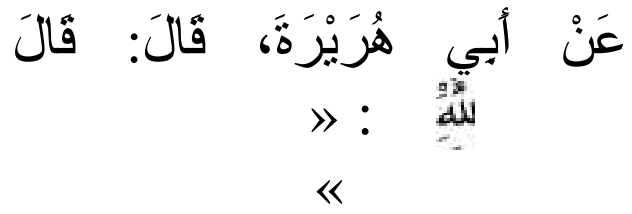

Artinya:
Dari Abu Hurairah berkata;

Rasulullah shallallahu 'alaihi wasallam bersabda: "Hanyasanya aku diutus untuk menyempurnakan akhlaq yang baik ( Hanbal, Juz 14, h. 512).

\section{Hadits tentang konsep pendidikan karakter}

Hadits Nabi yang berkaitan dengan konsep pendidikan karakter adalah hadits yang diriwayatkan oleh imam Bukhari, Muslim dan Ahmad sebagai berikut,

قال أسامة بن زبد رضي الله عنهما

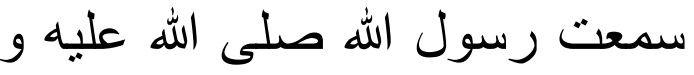

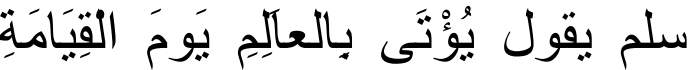

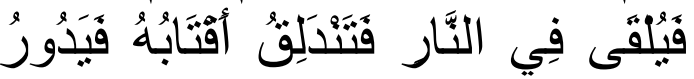

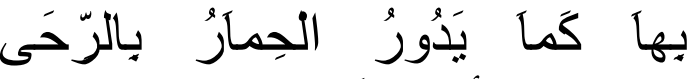

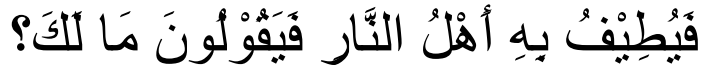

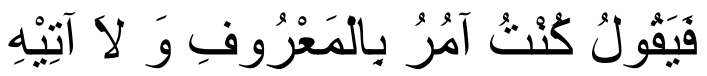

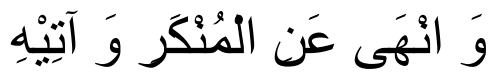

Artinya:

"Usamah bin Zaid ra. berkata: Saya mendengar Rasulullah saw. bersabda: Akan dihadapkan orang yang berilm u pada hari kiamat, lalu keluarlah sетиa isi perutnya, lalu ia berputar-putar dengannya, sebagaimana himar yang berputar-putar mengelilingi tempat tambatannya. Lalu penghuni neraka disuruh mengelilinginya seraya bertanya: Apakah yang menimpamu? Dia menjawab: Saya pernah menyuruh orang pada kebaikan, 
tetapi saya sendiri tidak mengerjakan-nya, dan saya mencegah orang dari $k e j$ ahatan, tetapi saya sendiri yang mengerjakannya”.

Menurut tinjuan Abu Bakar Muhammad (1997: 70) dalam bukunya Hadits Tarbawi, hadits ini beberapa pelajaran yang harus diperhatikan oleh para sarjana khususnya dan orangorang yang berilmu pada khususnya:

1. Setiap orang yang berilmu, teritama para ulama, sarjana, pembesar, guru dan dosen, termasuk para muballigh dan khotib, harus konsekuen mengamalkan ilmunya untuk kesejahteraan umat manusia.

2. Semua orang berilmu harus menjadi teladan bagi orang lain dalam tutur kata dan tingkah lakunya.

3. Orang berilmu yang tidak konsekuen dengan tutur katanya, diancam dengan siksaan yang berat dalam neraka kelak.

4. Dalam hadits tersebut terkandung larangan kepada para pembesar, ulama, muballigh, guru dan dosen, berakhlak tercela.

Dalam hadits riwayat di atas menguraikan bahwa pembentukan karakter yang didasari keteladanan akan menuai kebaikan bagi dirinya sendiri dan orang lain. Dengan bukti adanya siksa Allah bagi orang yang hanya memerintahkan suatu kebaikan namun ia tidak turut menjalankannya. Oleh karenanya, pengaruh keluarga sebagai tempat pendidikan pertama bagi sang anak harus berupa orang-orang yang baik pula. Beberapa pandangan dari para ilmuwan dari Barat menyoroti masalah pendidikan dikenal adanya tiga teori:

a. Teori Nativisme

Menurut Mustafa (2007: 39) teori ini mengemukakan bahwa manusia yang dilahirkan telah memiliki bakatbakat dan pembawaan baik karena berasal dari keturunan orang tuanya, nenek moyangnya maupun karena ditakdirkan demikian, yang penganutnya antara lain: Scopenhauer yang mengatakan bahwa manusia itu tidak berubah-ubah, akhlak manusia tetap seumur hidup.

Penganut teori ini mengatakan $b$ ahwa lingkungan sekitar manusia tidak akan memberi pengaruh apa-apa dalam per-kembangan manusia, jika manusia membawa potensi jahat maka dalam perkembangannya ia akan menjadi jahat dan begitu juga sebaliknya, jika manusia sejak lahir membawa potensi baik, maka perkembangan hidup selanjutnya akan menjadi baik pula (Mudyarahardjo, 1995: 198).

\section{b. Teori Empirisme}

Teori kedua ialah teori Empirisme (teori lingkungan). Menurut M. Furqon Hidayatullah (2010: 100) yang mengemukakan bahwa anak yang lahir itu laksana kertas yang putih bersih atau semacam tabularasa (meja lilin), di mana kertas dapat ditulisi dengan tinta macam warna apa saja. Inilah teori John Lock, yang agak mirip atau mengikuti teori Rasulullah tersebut, yaitu bahwa anak dilahirkan dalam keadaan suci bersih, tergantung kedua orang tuanya, yang akan mencetaknya akan jadi apa anaknya itu. 
Dalam perspektif pendidikan teori ini menganggap bahwa pendidik sangat memegang peranan yang sangat penting terhadap peserta didik, sebab pendidik akan menyediakan lingkungan semaksimal mungkin sesuai dengan yang dikehendaki oleh peserta didik. lingkungan pendidikan ini kemudian disajikan dan dikondisi-kan oleh pendidik kepada peserta didik sebagai pengalaman-pengalaman dalam kehidupannya dan selanjutnya melalui pengalaman-pengalaman tersebut akan membentuk pengetahuan, sikap dan tingkah laku peserta didik sesuai dengan tujuan pendidikan yang diharapkan Menurut A. Fatah Yasin (2008: 60).

\section{c. Teori Konvergensi}

Teori yang ketiga adalah teori konvergensi atau persesuaian di antara dua teori ( $\mathrm{M}$. Furqon Hidayatullah 2010: 100). Teori ini dipelopori oleh William Stern dari Jerman dengan pandangan yang lebih akomodatif. Hasil sintesa tersebut mengatakan bahwa manusia lahir di dunia ini telah membawa bakat. Bakat itu tidak akan berfungsi jika tidak dikembangkan oleh lingkungan sekelilingnya. Jadi, pembawaan dan lingkungan adalah dua hal yang tidak dapat dipisahkan. Lingkungan mendukung, tetapi bila bakat tidak ada maka pribadi manusia sulit untuk bisa berkembang dan sebaliknya, bila bakat itu ada tetapi lingkungan tidak mendukung juga sulit untuk berkembang ( Yasin: 2008: 60).

Dalam pandangan Islam, teori konvergensi inilah yang hampir memiliki kesamaan. Hanya saja yang membedakan bahwa dalam Islam manusia sejak lahir telah membawa fitrah, yang tercermin dalam beragama Islam.

Sebagaimana dalam sebuah Hadis riwayat Bukhori-Muslim, "Tiap manusia dilahirkan membawa fitrah (potensi), kedua orang tuanyalah yang menjadikannya Yahudi, Nasrani atau Majusi" (Bukhari, Juz 5: 52 dan Muslim, Juz 4: 2047), mengandung makna bahwa, manusia lahir di dunia ini membawa fitrah, atau dalam bahasa pendidikan sering disebut potensi atau kemampuan dasar, atau dalam istilah psikologi disebut pembawaan (hereditas). Fitrah itu akan berkembang tergantung dari bagaimana lingkungan itu mempengaruhi.

Lingkungan manusia yang paling awal dan utama dalam membentuk dan mempengaruhi perkembangan manusia sejak lahir adalah lingkungan keluarga. Anak manusia akan tumbuh dan berkembang menjadi manusia yang $\mathrm{m}$ emiliki sifat dan karakter seperti kaum Yahudi, Nasrani atau Majusi, sangat tergantung dari didikan dalam keluarga terutama yang diberikan oleh kedua orang tua (Yasin, 2008: 60).

Konsep fithrah dalam al-Qur'ân juga bertentangan dengan teori yang menganggap, manusia itu sesungguhnya suci bersih. Pendukung aliran Behaviorisme dalam psikologi memandang bahwa manusia itu ketika dilahirkan tidak mempunyai kecenderungan baik maupun jahat. Teori seperti ini yang kemudian disebut dengan "Teori Tabula Rasa", lingkunganlah yang memainkan peranan dalam membentuk kepribadiannya. Menurut Skinner (Abdullah 1994: 6162), "lingkungan menentukan kehidupan 
manusia ketika manusia ini melibatkan dirinya dengan lingkungan sekitar", maka manusia bukan warisan yang lebih dari refleksi -refleksi. Agama sebagaimana aspek-aspek lain dari tingkah laku manusia dapat diwujudkan ke dalam terma-terma mengenai faktorfaktor lingkungan sekitar. Kenyataan menyebutkan, bahwa anak dari seorang muslim biasanya menjadi muslim, sedangkan dari keturunan Kristen biasanya beragama Kristen. Bukti ini dicatat oleh Skinner sebagai contoh untuk menjelaskan teorinya.

Tidak diragukan lagi, periode defensi yang panjang selain pada masa kanak-kanak memberikan kemungkinan orang tuanya memberi pengaruh sangat besar bagi putra-putrinya. Fakta ini menurut Abdurrahman Saleh (1994: 62) dalam bukunya Teori-teori Pendidikan Berdasarkan Al-Qur'ân nampaknya telah menarik perhatian Skinner berkenaan dengan Hadits Nabi saw. yang menunjukkan bagaimana fithrah itu dipengaruhi lingkungan.

Hadits Nabi: "Tidaklah seorang anak itu dilahirkan, melainkan mempunyai fithrah Islam. Maka orang tuanyalah yang mempengaruhim enjadi Yahudi, Nashrani atau Majusi" menekankan, bahwa fithrah yang dibawa sejak lahir bagi anak itu sangat besar dipengaruhi oleh lingkungan. Fithrah itu sendiri tidak akan berkembang tanpa dipengaruhi kondisi lingkungan sekitar, yang mungkin dapat dimodifikasikan atau dapat diubah secara drastis manakala lingkungannya itu tidak memungkinkan menjadikannya lebih baik.

Mencermati hadits-hadits tersebut dapat dipahami bahwa pendidikan, utamanya pendidikan yang diberikan kedua orang tua terhadap anak-anaknya memiliki pengaruh yang sangat besar dalam pengembangan fithrah anak, karena pada dasarnya anak memiliki sifat dasar atau kecenderungan beragama yang lurus yaitu agama tauhid, hanya saja persoalannya kemudian bagaimana kedua orang tua "khususnya" dan lembaga pendidikan/sekolah serta masyarakat lingkungan di mana peserta didik berada memberikan pendidikan kepadanya. Masalah pendidikan sesungguhnya terdapat tiga titik sentral dalam pendidikan anak yaitu, keluarga, sekolah dan masyarakat, yang ketiganya saling terkait terintegrasi dan tidak mungkin dipisah-pisahkan (Juwairiyah, 2010:6-7).

Menurut penulis, teori yang dikemukakan dalam Hadits merupakan penguatan dari tujuan awal Allah menciptakan manusia, yaitu sebagai khalifah di bumi. Dalam arti luas khalifah dimaksudkan bukan hanya memimpin dan bertanggung jawab pada alam dan seisinya, namun manusia juga memiliki kewajiban untuk bertanggung jawab pada dirinya sendiri untuk mengasah dan mengembangkan potensi baik dengan perbuatan dan pembiasaan yang baik pula (amal shalih).

Menurut Sayadi, (2009: 168) mengetahui fithrah sebagai potensi dan sifat dasar manusia adalah sangat penting dan besar manfaatnya, yakni:

1. Pemahaman atas fitrah akan memberikan harapan y ang optimisakan penyelamatan dan 
kesuksesan dalam menata kehidupan ke arah masa depan.

2. Pemahaman atas fitrah akan menanamkan kepercayaan diri melalui potensinya sendiri untuk melakukan sesuatu yang baik dan benar dan menolak yang jahat dan salah.

3. Pemahaman atas fitrah akan memacu dan mendorong untuk secara aktif mengejar semua yang baik dan benar serta menolak se gala yang jahat dan keliru.

Menurut M. Quraish Shihab (2008: 724), keteladanan diperlukan karena tidak jarang nilai-nilai yang bersifat abstrak itu tidak dipahami, bahkan tidak terlihat keindahan dan manfaatnya oleh orang kebanyakan. Halhal abstrak dijelaskan dengan perumpamaan yang konkret dan indrawi. Keteladanan, dalam hal ini, melebihi dalam perumpamaan itu dalam fungsi dan peranannya. Itu pula sebabnya maka keteladanan diperlukan dan memiliki peranan yang sngat besar dalm mentransfer sifat dan karakter.

\section{KESIMPULAN}

Berdasarkan pembahasan di atas, maka dapat kami simpulkan.

1. Pendidikan karakter adalah penanamkan karakter tertentu sekaligus memberi benih agar peserta didik mampu menumbuhkan karakter khasnya pada saat menjalani kehidupannya.

Hanya menjalani sejumlah gagasan atau

model karakter saja tidak akan m embuat peserta didik menjadi man usia kreatif yang tahu bagaimana menghadapi perubahan zaman, sebaliknya membiarkan sedari awal agar peserta didik mengembangkan nilai pada dirinya tidak akan berhasil mengingat peserta didik tidak sedari awal menyadari kebaikan dirinya.

2. Sementara konsep pendidikan karakter dalam hadits adalah sebagai berikut:

a. Pembentukan karakter yang didasari keteladanan akan menuai kebaikan bagi dirinya sendiri dan orang lain. Oleh karena itu, pengaruh keluarga sebagai tempat pendidikan pertama bagi sang anak harus berupa orang-orang yang baik pula.

b. Dalam pandangan Islam, manusia lahir di dunia ini membawa fitrah, potensi, kemampuan dasar, atau pem bawaan. Fitrah itu akan berkembang tergantung dari bagaimana lingkungan itu mempengaruhi.

\section{DAFTAR PUSTAKA}

Yasin, A Fatah, Dimensi-dimensi Pendidikan Islam, Malang: UIN Malang Press, 2008

Muhammad, Abu Bakar, Hadits Tarbawi III, Surabaya: Karya Abditama, 1997

Abdullah, Abdurrahman Saleh, Teoriteori Pendidikan Berdasarkan 
Al-Qur'an, Jakarta: Rineka Sayadi, Wajidi, Hadis Tarbawi: PesanCipta, 1994.

Q-Anees, Bambang, dan pesan Nabi Saw. Tentang Pendidikan, Jakarta: Pustaka Adang Hambali, Pendidikan Karakter Berbasis Al-Qur'ân, Bandung: PT. Simbiosa Rekatama Media, 2008.

Suprayogo, Imam, Generasi Miskin Tauladan,http://www.facebook. com, diakses pada tanggal 5 Februari 2013.

al-Bukhari, al-Ja'fi, Muhammad bin Isma'il Abi Abdullah. Sahih alBukhari, Juz IV, Cet. 1; Dar T\}auq al-Najah, 1422 H., t.t.

Juwairiyah, Hadits

Tarbawi,

Yogyakarta: Teras, 2010

Hidayatullah, M. Furqon, Guru Sejati: Membangun Insan Berkarakter Kuat dan Cerdas, Surakarta: Yuma Pustaka, 2010

Shihab, M. Quraish, Membumikan AlQur'ân, Jakarta: Lentera Hati, 2008.

Ni'matulloh.et. all, Pendidikan Karakte $r$ Dalam Persfektif Pendidika n Islam,http://nimatulloh.blogs pot.com, diakses pada tanggal 5 Februari 2013.

Mudyarahardjo, Redja dkk., Materi Pokok Dasar-dasar Kependidikan, Jakarta: Universitas Terbuka, 1995. 